J. Dairy Sci. 98:2245-2259

http://dx.doi.org/10.3168/jds.2014-8902

(C) American Dairy Science Association ${ }^{\circledR}, 2015$.

\title{
Modeling of coagulation, curd firming, and syneresis of milk from Sarda ewes
}

\author{
G. M. Vacca, ${ }^{*}$ M. Pazzola, ${ }^{* 1}$ M. L. Dettori,, ${ }^{*}$ E. Pira, ${ }^{*}$ F. Malchiodi, $†$ C. Cipolat-Gotet, $†$ A. Cecchinato, $\dagger$ \\ and G. Bittante† \\ *Department of Veterinary Medicine, University of Sassari, Via Vienna 2, 07100 Sassari, Italy \\ †Department of Agronomy, Food, Natural Resources, Animals and Environment (DAFNAE), University of Padova, \\ viale dell'Università 16-35020 Legnaro (PD), Italy
}

\section{ABSTRACT}

This study investigated the modeling of curd-firming $(\mathrm{CF})$ over time $\left(\mathrm{CF}_{\mathrm{t}}\right)$ of sheep milk. Milk samples from 1,121 Sarda ewes from 23 flocks were analyzed for coagulation properties. Lactodynamographic analyses were conducted for up to $60 \mathrm{~min}$, and $240 \mathrm{CF}$ individual observations from each sample were recorded. Individual sample $\mathrm{CF}_{\mathrm{t}}$ equation parameters $\left(\mathrm{RCT}_{\mathrm{eq}}\right.$, rennet coagulation time; $\mathrm{CF}_{\mathrm{P}}$, asymptotic potential value of curd firmness; $\mathrm{k}_{\mathrm{CF}}$, curd-firming instant rate constant; and $\mathrm{k}_{\mathrm{SR}}$, curd syneresis instant rate constant) were estimated, and the derived traits $\left(\mathrm{CF}_{\max }\right.$, the point at which $\mathrm{CF}_{\mathrm{t}}$ attained its maximum level, and $\mathrm{t}_{\max }$, the time at which $\mathrm{CF}_{\max }$ was attained) were calculated. The incidence of noncoagulating milk samples was $0.4 \%$. The iterative estimation procedure applied to the individual coagulation data showed a small number of not-converged samples (4.4\%), which had late coagulation and an almost linear pattern of the ascending part of the $\mathrm{CF}_{\mathrm{t}}$ curve that caused a high value of $\mathrm{CF}_{\mathrm{P}}$, a low value of $\mathrm{k}_{\mathrm{CF}}$, and a high value of $\mathrm{k}_{\mathrm{SR}}$. Converged samples were classified on the basis of their $\mathrm{CF}_{\mathrm{t}}$ curves into no- $\mathrm{k}_{\mathrm{SR}}(18.0 \%)$, low- $\mathrm{k}_{\mathrm{SR}}(72.6 \%)$, and high- $\mathrm{k}_{\mathrm{SR}}(4.5 \%) . \mathrm{A} \mathrm{CF}_{\mathrm{t}}$ that was growing continuously because of the lack of the syneresis process characterized the no- $\mathrm{k}_{\mathrm{SR}}$ samples. The high- $\mathrm{k}_{\mathrm{SR}}$ samples had a much larger $\mathrm{CF}_{\mathrm{P}}$, a smaller $\mathrm{k}_{\mathrm{CF}}$, and an anticipation of $\mathrm{t}_{\max }$, whereas the low- $\mathrm{k}_{\mathrm{SR}}$ samples had a fast $\mathrm{k}_{\mathrm{CF}}$ and a slower $\mathrm{k}_{\mathrm{SR}}$. The part of the average $\mathrm{CF}_{\mathrm{t}}$ curves that showed an increase was similar among the 3 different syneretic groups, whereas the part that decreased was different because of the expulsion of whey from the curd. The traditional milk coagulation properties recorded within 30 min were not able to detect any appreciable differences among the 4 groups of coagulating samples, which could lead to a large underestimation of the maximum $\mathrm{CF}$ of all samples (if predicted by $\mathrm{a}_{30}$ ), with the exception of the no- $\mathrm{k}_{\mathrm{SR}}$ samples. Large

Received September 26, 2014

Accepted December 22, 2014.

${ }^{1}$ Corresponding author: pazzola@uniss.it individual variability was found and was likely caused by the effects of the dairy system, such as flock size (on $\mathrm{CF}_{\max }, \mathrm{t}_{\max }$, and $\%$ ewes with no- $\mathrm{k}_{\mathrm{SR}}$ milk), flock within flock size (representing 11 to $43 \%$ of total variance for $\%$ ewes with no-k $\mathrm{k}_{\mathrm{SR}}$ milk and $\mathrm{CF}_{\max }$, respectively), days in milk (on all model parameters and $\mathrm{CF}_{\max }$ ), parity (on $\mathrm{RCT}_{\mathrm{eq}}, \mathrm{k}_{\mathrm{SR}}$, and $\mathrm{CF}_{\max }$ ), daily milk yield (on $\mathrm{RCT}_{\mathrm{eq}}$ and $\mathrm{CF}_{\max }$ ), and position of the individual pendulum that significantly affected model parameters and derived traits. In conclusion, the results showed that the modeling of coagulation, curd-firming, and syneresis is a suitable tool to achieve a deeper interpretation of the coagulation and curd-firming processes of sheep milk and also to study curd syneresis.

Key words: ovine milk, milk coagulation property, curd-firming modeling, syneresis, cheese-making property

\section{INTRODUCTION}

The production of milk from species other than bovine contributes significantly in certain countries (Claeys et al., 2014). World total production of ewe milk during 2001 to 2011 increased from 8.3 to 9.9 million tonnes, and gross production value increased from US $\$ 3,100$ to 5,600 million (FAOSTAT, 2014). Because the large majority of sheep milk is used for the production of cheese, industries making cheese from sheep milk benefit from significant information about coagulation properties obtained in the laboratory and dairy. This information is often acquired with methods developed from studies on dairy cows.

The traditional milk coagulation properties (MCP), rennet coagulation time (RCT, min), curd-firming time $\left(\mathbf{k}_{\mathbf{2 0}}, \mathbf{m i n}\right)$, and curd firmness $\left(\mathbf{a}_{\mathbf{3 0}}, \mathbf{m m}\right)$, are single-point parameters that were introduced for the study and the evaluation of the requirements of cow milk for cheese making. The MCP are often determined by mechanical lactodynamographic instruments that measure curd formation and firmness during a 30-min test (McMahon and Brown, 1982; Cipolat-Gotet et al., 2012). Those measurements are often criticized because 
of concerns about the method: MCP are obtained from a time-consuming analysis and from milk samples with a delayed RCT (tests that are longer than 30 min and classified as noncoagulating samples, NC), it is not possible to determine any MCP values (Ikonen et al., 1999; Wedholm et al., 2006). The NC samples are often recorded for bovine species because some breeds (e.g., the Holstein-Friesian), are characterized by a latecoagulating milk (Verdier-Metz et al., 1998; Malacarne et al., 2006; Cecchinato et al., 2011). The NC samples are treated by extending the analysis for longer than 30 min (Auldist et al., 2004; Poulsen et al., 2013).

Modeling the entire output of computerized lactodynamographs and the introduction of the concept of curd-firming over time $\left(\mathbf{C F}_{\mathbf{t}}\right)$, which is independent from the traditional MCP, provides additional information about milk coagulation and the curd-firming processes (Bittante, 2011). This last approach has been first studied in dairy cows to provide novel parameters and to summarize all of the information collected by the continuous recording of $\mathrm{CF}_{\mathrm{t}}$ observations for each sample, which includes the asymptotic potential value of curd firmness at an infinite time $\left(\mathbf{C F}_{\mathbf{P}}, \mathbf{m m}\right)$ and the curd-firming instant rate constant $\left(\mathbf{k}_{\mathrm{CF}}, \% \times \min ^{-1}\right)$. The RCT is not predicted as a single point measurement but from the result of modeling all data available $\left(\mathbf{R C T}_{\mathbf{e q}}, \mathbf{m i n}\right)$. Moreover, the modeling of data obtained from prolonging the lactodynamographic test beyond the usual 30 min also lead to information on the syneresis process: a syneresis instant rate constant $\left(\mathbf{k}_{\mathrm{SR}}, \% \times \min ^{-1}\right)$ that tends to reduce $\mathrm{CF}_{\mathrm{t}}$ beyond a maximum curd firmness $\left(\mathbf{C F}_{\max }, \mathrm{mm}\right)$ after a given time interval $\left(\mathbf{t}_{\max }, \min \right)$, according to the 4 parameter model of Bittante et al. (2013).

Although the incidence is lower than in bovines, the presence of NC is observed in sheep (Pazzola et al., 2013) and goats (Devold et al., 2010; Pazzola et al., 2012, 2014b). Pazzola et al. (2014a) have analyzed the MCP of milk samples collected in a large survey on dairy Sarda ewes, and outlined the limitations of applying the traditional MCP for dairy cows to sheep species and the need for modeling of the available information. Modeling has been used for sheep species by Bittante et al. (2014), who have applied a 4-parameter model to a limited population of Alpine sheep breeds reared under experimental conditions.

The present study had the following objectives: (1) to test the adaptability of a 4-parameter model to depict the pattern of single point $\mathrm{CF}$ measurements recorded during an extended interval of time from rennet addition to sheep milk samples; (2) to classify milk samples collected during a large survey on Sarda sheep flocks according to the parameters of the models; and (3) to analyze the effects of flock, of individual ewe character- istics (parity, stage of lactation, and daily milk yield) and of instrument position (pendulum) on the model parameters and derived traits.

\section{MATERIALS AND METHODS}

\section{Animals and Milk Sampling}

Pazzola et al. (2014a) have described in detail the animals and milk sampling procedures adopted for the present study. Briefly, 1,121 ewes reared on 23 different commercial farms evenly distributed over the island of Sardinia, Italy, were used in the study. Lactating ewes were pasture-fed with a commercial concentrate supplementation given during the milking and were generally managed following the common semi-extensive and semi-intensive methods as described by Carta et al. (2009) and Carcangiu et al. (2011). The flock size $(<300$ ewes, 8 flocks; $300-600$ ewes, 7 flocks; and $>600$ ewes, 8 flocks) was found to be the herd classification factor (flock size, geographic area, type of operation, type of farm on the basis of management, and feeding characteristics) that maximized the fit of the model and that avoided multicollinearity among different management factors (Pazzola et al., 2014a). Ewe milking was performed by manually operated milking machines twice a day (often at 600 and $1600 \mathrm{~h}$ ). The daily milk yield was $1.61 \pm 0.83 \mathrm{~kg}$. Groups of ewes (32 to 82 per flock) in the second to the seventh month of lactation were sampled once (DIM $140 \pm 42 \mathrm{~d}$ ).

\section{Analyses of Milk Traits and Coagulation Properties}

Pazzola et al. (2014a) have described the analyses and the mean values for milk contents. The chemical composition (fat, protein, casein, urea, and lactose and $\mathrm{pH})$ of individual milk samples was analyzed with a MilkoScan FT6000 (Foss Electric, Hillerød, Denmark). The SCC was determined with a Fossomatic 5000 (Foss Electric), and the total bacterial count (TBC) was measured with a BactoScan FC150 (Foss Electric). Both SCC and TBC were log-transformed: SCC to SCS $\left.\left[\mathrm{SCS}=\left(\log _{2} \mathrm{SCC} \times 100,000^{-1}\right)+3\right)\right]$ and $\mathrm{TBC}$ to log-bacterial count $\left[\mathrm{TBC}=\log _{10}\right.$ (total bacterial count $\left.\times 1,000^{-1}\right)$ ]. The measures of MCP were obtained with the Formagraph instrument (Foss Italia, Padova, Italy). For each individual sample, $10 \mathrm{~mL}$ was heated to $35^{\circ} \mathrm{C}$ before the addition of $200 \mu \mathrm{L}$ of the rennet solution [Hansen Naturen Plus 215 (Pacovis Amrein AG, Bern, Switzerland), with $80 \pm 5 \%$ chymosin and $20 \pm 5 \%$ pepsin and 215 international milk clotting units (IMCU) $/ \mathrm{mL}$, which was diluted to $1.2 \%$ (wt/ vol) in distilled water to achieve $0.0513 \mathrm{IMCU} / \mathrm{milk}$ $\mathrm{mL}$. This analysis continued for $60 \mathrm{~min}$ after rennet 


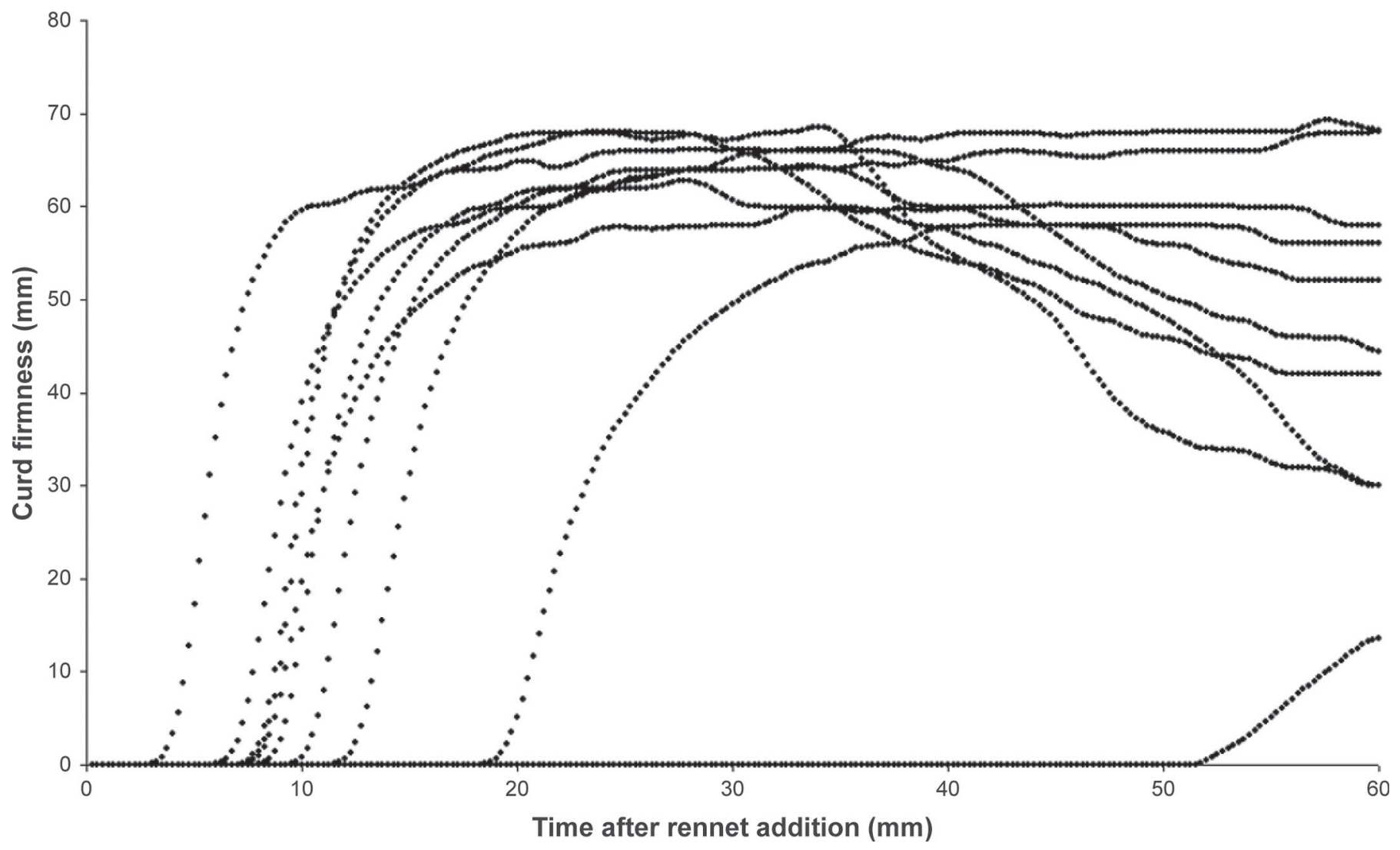

Figure 1. Graph reporting the 240 curd firmness individual point observations up to 60 min after rennet addition (1 point every $15 \mathrm{~s})$ of 10 different individual ewes.

addition, and the related traditional coagulation single point traits (RCT, $\mathrm{k}_{20}$, and $\mathrm{a}_{30}$ ) were recorded (McMahon and Brown, 1982). Moreover, curd firmness was also recorded at $45\left(\mathbf{a}_{45}\right)$ and $60 \mathrm{~min}\left(\mathbf{a}_{\mathbf{6 0}}\right)$ after rennet addition. A few milk samples did not coagulate within the 60 min duration of the lactodynamographic test and these were excluded from the statistical analyses ( 5 out of 1,121 samples, $0.4 \%$ ).

\section{Coagulation, Curd Firmness, and Syneresis Modeling}

During testing, the Formagraph apparatus recorded the width $(\mathrm{mm})$ of the oscillatory graph every $15 \mathrm{~s}$ after rennet addition, and as a consequence, a total of $240 \mathrm{CF}$ individual point observations were recorded for each analyzed milk sample. Extending the recording to $60 \mathrm{~min}$ allowed us to observe the differences in $\mathrm{CF}$ graphs of the individual ewes (Figure 1) and for a test of the 4-parameter model described by Bittante et al. (2013):

$$
\mathrm{CF}_{\mathrm{t}}=\mathrm{CF}_{\mathrm{P}} \times\left(1-e^{-\mathrm{k}_{\mathrm{CF}} \times\left(\mathrm{t}-\mathrm{RCT}_{\mathrm{eq}}\right)} \times e^{-\mathrm{k}_{\mathrm{SR}} \times\left(\mathrm{t}-\mathrm{RCT}_{\mathrm{eq}}\right)},\right.
$$

where $\mathrm{CF}_{\mathrm{t}}$ is the curd firmness at time $\mathrm{t}(\mathrm{mm}), \mathrm{CF}_{\mathrm{P}}$ is the asymptotic potential maximum value of curd firmness $(\mathrm{mm}), \mathrm{k}_{\mathrm{CF}}$ is the curd-firming instant rate constant $(\% / \mathrm{min}), \mathrm{k}_{\mathrm{SR}}$ is the curd syneresis instant rate constant $(\% / \mathrm{min})$, and $\mathrm{RCT}_{\mathrm{eq}}$ is the rennet coagulation time estimated by the model ( $\mathrm{min}$ ).

The model parameters for ewe milk are illustrated in a previous study on the technological properties of milk from Alpine sheep breeds (Bittante et al., 2014). That model uses all of the 240 available CF measures recorded for each milk sample during the 60 min test to estimate the 4 parameters, which are not single-point measurements, in contrast to traditional MCP. The $\mathrm{CF}_{\mathrm{P}}$ parameter is conceptually independent from test duration, and unlike $\mathrm{a}_{30}$, is not intrinsically dependent on RCT. The parameter $\mathrm{k}_{\mathrm{CF}}$ is assumed to increase $\mathrm{CF}$ toward the $\mathrm{CF}_{\mathrm{P}}$ asymptotic value, whereas $\mathrm{k}_{\mathrm{SR}}$ is assumed to decrease CF toward a null asymptotic value. In the initial phase of the test, the first rate constant prevails over the second, and the $\mathrm{CF}_{\mathrm{t}}$ increases to a point in time $\left(t_{\max }\right)$, at which point the effects of the 2 parameters are equal but opposite in sign, and $\mathrm{CF}_{\mathrm{t}}$ attained its maximum level $\left(\mathrm{CF}_{\max }\right)$. Thereafter, $\mathrm{CF}_{\mathrm{t}}$ be- 
gins to decrease and tends toward a null value because of the effect of curd syneresis and the corresponding expulsion of whey. The $\mathrm{RCT}_{\text {eq }}$ parameter conceptually corresponds to the traditional RCT measure, but it is estimated with the model's parameters using all available data.

For milk samples that showed a continuous increase of $\mathrm{CF}\left(\mathrm{t}_{\max }=60 \mathrm{~min}\right)$ or that had a flat pattern in the last part of the curve $\left(\mathrm{t}_{\max }<60 \mathrm{~min}\right)$, the 4-parameter model did not interpolate the experimental observations well. In these cases, $\mathrm{k}_{\mathrm{SR}}$ was assumed to be equal to zero and therefore a simplified 3 parameter model (without the $\mathrm{k}_{\mathrm{SR}}$ to explain the decreasing part of the curve) was applied, according to Bittante (2011) as follows:

$$
\mathrm{CF}_{\mathrm{t}}=\mathrm{CF}_{\mathrm{P}} \times\left(1-e^{-\mathrm{k}_{\mathrm{CF}} \times\left(\mathrm{t}-\mathrm{RCT}_{\mathrm{eq}}\right)}\right) .
$$

\section{Statistical Analyses}

The $240 \mathrm{CF}_{\mathrm{t}}$ point observations for each sample were fitted with curvilinear regressions using the nonlinear procedure (PROC NLIN) of the SAS software (SAS Institute Inc., 2001). The parameters of each individual equation were estimated with the Marquardt iterative method (350 iterations and a $10^{-5}$ level of convergence). In some cases (49 of 1,121 samples, 4.4\%), data did not converge.

The samples with convergent equations were classified according to the $\mathrm{k}_{\mathrm{SR}}$ parameter as follows: no- $\mathrm{k}_{\mathrm{SR}}$ for milk samples with a $\mathrm{k}_{\mathrm{SR}}=0.00 \% / \mathrm{min}$; low- $\mathrm{k}_{\mathrm{SR}}$ for samples with a $0.00<\mathrm{k}_{\mathrm{SR}}<3.00 \% / \mathrm{min}$; and high- $\mathrm{k}_{\mathrm{SR}}$ for samples with $\mathrm{k}_{\mathrm{SR}} \geq 3.00 \% / \mathrm{min}$.

The $\mathrm{CF}_{\mathrm{t}}$ parameters, $\mathrm{CF}_{\mathrm{P}}, \mathrm{k}_{\mathrm{CF}}, \mathrm{k}_{\mathrm{SR}}$, and $\mathrm{RCT}_{\mathrm{eq}}$, and the derived traits, $\mathrm{CF}_{\max }$ and $\mathrm{t}_{\max }$, determined from the modeling of curd firmness were analyzed using the GLM procedure of the SAS software (SAS Inst. Inc., Cary, NC) and with the following linear model from Pazzola et al. (2014a):

$$
\begin{aligned}
\mathrm{y}_{\mathrm{ijklmno}}= & \left.\mu+\text { flock-size }_{\mathrm{m}}+\text { flock (flock-size }\right)_{\mathrm{n}: \mathrm{m}}+\mathrm{DIM}_{\mathrm{i}} \\
& + \text { parity }_{\mathrm{j}}+\mathrm{MUCM}_{\mathrm{k}}+\mathrm{MY}_{\mathrm{l}}+\mathrm{e}_{\mathrm{ijklmno}},
\end{aligned}
$$

where $\mathrm{y}_{\mathrm{ijklmno}}$ is the analyzed variable, $\mu$ is the overall intercept of the model, flock-size $\mathrm{m}_{\mathrm{m}}$ is the fixed effect of mth flock size $(\mathrm{m}=1-3$; class $1:<300$ ewes; class 2 : 300 to 600 ewes; class $3:>600$ ewes), flock (flock-size) n:m $_{\text {is }}$ is the random effect of the flock-test-day nested within flock size, $D_{I M}$ is the fixed effect of the ith class of days in milk ( $\mathrm{i}=1-8$; class 1 : from 61 to $80 \mathrm{~d}$; class 2: 81 100; class 3: 101-120; class 4: 121-140; class 5: 141-160; class 6: 161-180; class 7: 181-200; and class 8: >200 d), parity $_{j}$ is the fixed effect of the jth parity of the ewes $(j$
$=1$ to 5 or more), $\mathrm{MUCM}_{\mathrm{k}}$ is the fixed effect of the kth measuring unit of the coagulation meter $(\mathrm{k}=1$ to 10 , on the basis of the position of the individual pendulum), $\mathrm{MY}_{1}$ is the fixed effect of lth class of single testday milk yield $(1=1-7$; class $1:<0.60 \mathrm{~L}$; class 2 : from 0.60-0.99; class 3: $1.00-1.38$; class 4: 1.39-1.77; class 5: 1.78-2.17; class 6: 2.18-2.57; and class 7: $>2.57 \mathrm{~L}$ ), and $\mathrm{e}_{\mathrm{ijk} k \mathrm{mno}}$ is the random residual error. The flock-test-day nested within flock size and the residuals were considered to be independent and normally distributed with means of zero and variances of $\sigma_{F}^{2}$ and $\sigma_{e}^{2}$, respectively. The flock (flock-size) n:m was used as the error term to test the significance of flock size ${ }_{\mathrm{m}}$, whereas all other fixed effects were tested on residual variance.

The percentage of variance explained by the flock was computed from the ratio between the related component of variance and the total variance. The comparisons of least squares means of MCP were estimated by means of the following contrasts for the effect of (1) days in milk: (a) linear, (b) quadratic, and (c) cubic component; (2) parity: (a) primiparous vs. pluriparous, (b) secondiparous versus ewes at third-fourth-fifth parity, (c) ewes at third parity versus ewes at fourth-fifth parity, and (d) ewes at fourth parity versus ewes at fifth parity; and (3) daily milk production: (a) linear, (b) quadratic, and (c) cubic component.

\section{RESULTS AND DISCUSSION}

\section{Noncoagulating Milk Samples}

It is well known that in small ruminant species, such as sheep (Sevi et al., 2000; Jaramillo et al., 2008) and goats (Pazzola et al., 2011; Inglingstad et al., 2014), the coagulation processes throughout lactation are much more rapid than in dairy cows, and the percentages of NC samples are consequently lower (Pazzola et al., 2012; Bittante et al., 2014). In the present study, the incidence of NC milk samples for the Sarda sheep breed was lower than $1 \%$ (10 samples out of 1,121 did not coagulate within 30 min after rennet addition). One-half of these samples coagulated during the extended observation period, and only a few samples $(5,0.4 \%)$ did not coagulate within $60 \mathrm{~min}$ (Table 1). Data regarding the lactation stage, daily milk yield, and fat, protein, and casein content of NC samples (Table 2) were similar to those milk samples that coagulated within $30 \mathrm{~min}$. The data from ewes that presented evidence of clinical disease or mastitis were excluded from milk sampling. The milk composition (low casein number, lactose and urea content, high $\mathrm{pH}$, and particularly, SCS), when compared with the Sarda sheep in similar farming systems (Mura et al., 2012; Vacca et al., 2013), still suggested that the ewes that produced the $\mathrm{NC}$ samples 
were affected by subclinical mastitis, which is known to negatively affect milk coagulation and cheese yield in ovine species (Merin et al., 2004).

\section{Nonconverging Curd Firmness Model Equations}

The iterative estimation procedure applied to the 240 point measurements of $4.4 \%$ (49 of 1,121 ewes) of the milk samples for the estimation of the individual $\mathrm{CF}_{t}$ model parameters did not comply with the required convergence criteria. An incidence of $6.8 \%$ ( 85 of 1,243 cows) has been recorded in a large survey on Brown Swiss cows (Bittante et al., 2015). In both cows and ewes, the nonconvergent samples were characterized by a physico-chemical composition similar to the convergent samples (Table 2) but had a larger RCT than the average value $(+39 \%$ for ovine and $+76 \%$ for bovine species $)$ and especially of SD $(+195 \%$ for ovine and $+64 \%$ for bovine species). The variability of RCT in sheep milk, shown in Figure 2, was characterized by a leptokurtic $(+18.6)$ positively skewed $(+3.5)$ distribution.

Nonconvergent samples often showed a slightly less regular shape of the $C F_{t}$ curve (the $R^{2}$ values of each individual curve were $0.9929 \pm 0.0054$ for nonconvergent samples and $0.9988 \pm 0.0025$ for convergent samples) and showed a linear pattern for the ascending part of the curve that led to an estimation of a high value for the potential asymptotic curd-firming $\left(\mathrm{CF}_{\mathrm{P}}\right)$, which was compensated for by a low value of $\mathrm{k}_{\mathrm{CF}}$ and a high value of $\mathrm{k}_{\mathrm{SR}}$ (Table 1 ). This type of sample was the main source of the deviations from normality in the distribution of data for $\mathrm{CF}_{\mathrm{P}}$ and $\mathrm{k}_{\mathrm{CF}}$ (Figure 2). However, these large differences in the equation parameters did not lead to larger deviations in $t_{\max }$ and $\mathrm{CF}_{\max }$ (basically lower) than in the convergent samples (Table 1). If not-converged samples were characterized by an increase in RCT and a tendency for an increase of $\mathrm{k}_{20}$ and reductions of $\mathrm{a}_{30}, \mathrm{a}_{45}$, and $\mathrm{a}_{60}$, then the traditional MCP were not much affected (Table 1). However, larger differences concerning the traditional MCP have been observed in dairy cows (Bittante et al., 2015).

\section{Convergent Curd Firmness Model Equations and Sample Classification}

Milk samples from Sarda ewes that yielded a convergent equation were a large proportion of the total samples examined $(95.2 \%)$. The analyses of the distribution of $\mathrm{CF}_{\mathrm{t}}$ individual equation parameters (Figure 2) showed the effects of nonconvergent curves on the $\mathrm{CF}_{\mathrm{P}}$ and $\mathrm{k}_{\mathrm{CF}}$ estimates. The parameter with the highest deviation from normality was $\mathrm{k}_{\mathrm{SR}}$, which was charac- terized by a 3-modal skewed distribution. As stated in Materials and Methods, on the basis of this result, samples with convergent equations were classified into 3 groups: no- $\mathrm{k}_{\mathrm{SR}}$, low- $\mathrm{k}_{\mathrm{SR}}$, and high- $\mathrm{k}_{\mathrm{SR}}$.

An important proportion of the ewes that produced milk with convergent $\mathrm{CF}_{\mathrm{t}}$ equations, $18.9 \%$ (202 out of 1,067 milk samples), were characterized by a $\mathrm{CF}_{t}$ pattern that grew continuously during the observation interval or was flat in the last part of the period [i.e., without a decreasing phase and thus without an estimable $\mathrm{k}_{\mathrm{SR}}$ parameter (Table 1)]. This meant that the $\mathrm{CF}_{\text {max }}$ of these samples were observed at the end of the time interval (60 min), which were evident from the distribution of the $t_{\max }$ trait (Figure 3 ). This trend was confirmed by the traditional MCP because the no- $\mathrm{k}_{\mathrm{SR}}$ samples were the only ones characterized by increasing values moving from $\mathrm{a}_{30}$ to $\mathrm{a}_{45}$ and $\mathrm{a}_{60}$ (Table 1 ). In comparison with the other converging samples, no-k $\mathrm{k}_{\mathrm{SR}}$ samples were characterized by greater $\mathrm{a}_{30}(+21 \%), \mathrm{a}_{45}$ $(+44 \%)$, and $\mathrm{a}_{60}(+63 \%)$ values, but by similar RCT $(+2 \%)$ and $\mathrm{k}_{20}(-4 \%)$ values. The $\mathrm{CF}_{\mathrm{t}}$ model parameters obtained for no- $\mathrm{k}_{\mathrm{SR}}$ samples (Table 1) highlighted that the highest values of $\mathrm{CF}_{\max }$ and the growing values of curd firmness observed at given time intervals from rennet addition were not due to a greater potential $\mathrm{CF}$ $\left(\mathrm{CF}_{\mathrm{P}}\right)$ or to rapid increase of $\mathrm{CF}$ after gelation $\left(\mathrm{k}_{\mathrm{CF}}\right)$ but only to the lack of the syneresis process $\left(\mathrm{k}_{\mathrm{SR}}\right)$.

The incidence of no- $\mathrm{k}_{\mathrm{SR}}$ in the present study was lower than the average value of $23.3 \%$ that has been previously found for Alpine sheep breeds (Bittante et al., 2014). In that study, the incidence of no- $\mathrm{k}_{\mathrm{SR}}$ samples is not affected by the breed or the number of newborn lambs, but it is significantly influenced by a feeding effect; indeed, the control ewes fed an indoor total mixed ration without fresh forage show an incidence of no- $\mathrm{k}_{\mathrm{SR}}$ samples that is much higher than the ewes fed a diet supplemented with conjugated linoleic acid (30.8 vs. $15.7 \%$, respectively). In the present study, concerning specialized dairy ewes mainly fed on pasture, a natural source of CLA, the no-kSR incidence $(18.9 \%$ ) was similar to CLA-supplemented ewes of Bittante et al. (2014).

In the case of bovine species, the presence of no- $\mathrm{k}_{\mathrm{SR}}$ samples was not observed on samples tested for $90 \mathrm{~min}$ (Bittante et al., 2015). Additionally, Calvo and Balcones (2000) found differences in the syneresis process when comparing the milk samples from ovine and caprine species with those from bovines.

As shown in Figure 2, the $\mathrm{k}_{\mathrm{SR}}$ was characterized by a 3 -modal distribution with 2 extreme groups of samples, no- $\mathrm{k}_{\mathrm{SR}}$ samples with $\mathrm{k}_{\mathrm{SR}}=0.00 \% / \mathrm{min}$ and samples with high values of $\mathrm{k}_{\mathrm{SR}}(>3.00 \% / \mathrm{min})$. The number of samples with high $\mathrm{k}_{\mathrm{SR}}$ values, 51 out of $1,067(4.8 \%$, Table 1). Compared with the pattern shown by the no- $\mathrm{k}_{\mathrm{SR}}$ samples, the high- $\mathrm{k}_{\mathrm{SR}}$ samples had similar RCT 
Table 1. Descriptive statistics (least squares means $\pm \mathrm{SD}$ ) of curd-firming model parameters, of maximum curd firmness and of traditional coagulation properties (MCP) of Sarda ewe milk samples ${ }^{1}$

\begin{tabular}{|c|c|c|c|c|c|c|c|}
\hline \multirow[b]{2}{*}{ Item } & \multirow{2}{*}{$\begin{array}{c}\text { Not coagulated } \\
\text { samples }\end{array}$} & \multirow{2}{*}{$\begin{array}{l}\text { Not converged } \\
\text { equations }\end{array}$} & \multicolumn{3}{|c|}{ Converged equations } & \multicolumn{2}{|c|}{ References } \\
\hline & & & $\mathrm{No}_{\mathrm{SR}}$ & Low-k $\mathrm{k}_{\mathrm{SR}}$ & High-k $\mathrm{sR}_{\mathrm{SR}}$ & Sheep milk² & Cow milk ${ }^{3}$ \\
\hline Samples (no.) & 5 & 49 & 202 & 814 & 51 & 206 & 1,158 \\
\hline \multicolumn{8}{|l|}{$\mathrm{CF}_{+}$model parameters } \\
\hline $\mathrm{RCT}_{\mathrm{eq}}(\mathrm{min})$ & - & $13.3 \pm 11.5$ & $9.7 \pm 5.1$ & $9.6 \pm 3.6$ & $8.8 \pm 4.5$ & 8.4 & 19.9 \\
\hline $\mathrm{CF}_{\mathrm{P}}(\mathrm{mm})$ & - & $12,645 \pm 8,772$ & $60.8 \pm 6.9$ & $61.1 \pm 14.1$ & $175.8 \pm 121.7$ & 67.7 & 56.8 \\
\hline $\mathrm{k}_{\mathrm{CF}}(\%)$ & - & $0.1 \pm 0.5$ & $26.9 \pm 8.1$ & $30.0 \pm 12.3$ & $13.6 \pm 13.4$ & 42.2 & 13.0 \\
\hline $\mathrm{k}_{\mathrm{SR}}(\%)$ & - & $7.74 \pm 2.74$ & $0.00 \pm 0.00$ & $0.94 \pm 0.70$ & $4.74 \pm 1.34$ & 0.76 & 1.46 \\
\hline Maximum CF & - & & & & & & \\
\hline $\mathrm{CF}_{\max }(\mathrm{mm})$ & - & $49.2 \pm 14.6$ & $62.7 \pm 7.7$ & $52.8 \pm 8.1$ & $53.8 \pm 8.1$ & 61.7 & 37.3 \\
\hline \multirow{2}{*}{\multicolumn{8}{|c|}{ MCP }} \\
\hline & & & & & & & \\
\hline RCT (min) & - & $13.3 \pm 13.0$ & $8.8 \pm 5.2$ & $8.7 \pm 3.7$ & $8.1 \pm 4.5$ & 8.0 & 19.7 \\
\hline $\mathrm{k}_{20}(\min )$ & - & $2.3 \pm 1.2$ & $1.9 \pm 1.1$ & $2.0 \pm 0.7$ & $1.9 \pm 0.7$ & 1.6 & 5.0 \\
\hline $\mathrm{a}_{30}(\mathrm{~mm})$ & - & $40.2 \pm 19.6$ & $58.0 \pm 11.4$ & $48.8 \pm 11.1$ & $41.0 \pm 12.8$ & 57.5 & 30.2 \\
\hline $\mathrm{a}_{45}(\mathrm{~mm})$ & - & $26.5 \pm 21.1$ & $60.8 \pm 8.4$ & $44.4 \pm 12.1$ & $25.9 \pm 12.2$ & 52.6 & 33.5 \\
\hline $\mathrm{a}_{60}(\mathrm{~mm})$ & - & $13.9 \pm 9.7$ & $62.0 \pm 7.9$ & $40.5 \pm 12.3$ & $16.3 \pm 8.0$ & - & - \\
\hline
\end{tabular}

${ }^{1} \mathrm{CF}_{\mathrm{t}}=$ curd-firming over time; $\mathrm{RCT}_{\mathrm{eq}}=$ rennet coagulation time estimated on the basis of the $\mathrm{CF}_{\mathrm{t}}$ model; $\mathrm{CF}_{\mathrm{P}}=$ asymptotical curd firmness; $\mathrm{k}_{\mathrm{CF}}=$ instant curd firming rate constant; $\mathrm{k}_{\mathrm{SR}}=$ instant syneresis rate constant; $\mathrm{CF}_{\max }=$ maximum curd firmness; $\mathrm{t}_{\max }=$ time from rennet addition to the attainment of the $\mathrm{CF}_{\max } ; \mathrm{RCT}=$ rennet coagulation time; $\mathrm{k}_{20}$ $=$ curd-firming time (time to reach a curd firmness of $20 \mathrm{~mm}$ ); $\mathrm{a}_{30}, \mathrm{a}_{45}$, and $\mathrm{a}_{60}=$ curd firmness measured 30,45 , and 60 min after rennet addition. Not coagulated $=$ milk samples that did not coagulate within $60 \mathrm{~min}$ after rennet addition; not converged equations = milk samples with $\mathrm{CF}$ data not converging according to the $\mathrm{CF}_{\mathrm{t}}$ model, usually because of late coagulation and a small number of observations $>0$; no- $\mathrm{k}_{\mathrm{SR}}=$ milk samples that did not show a phase of decreasing curd firmness within 60 min after the phase of increase because of syneresis; low- $\mathrm{k}_{\mathrm{SR}}=$ milk samples characterized by a $\mathrm{k}_{\mathrm{SR}}<3 \% / \mathrm{min}$; and high- $\mathrm{k}_{\mathrm{SR}}=$ milk samples characterized by a $\mathrm{k}_{\mathrm{SR}}>3 \% / \mathrm{min}$.

${ }^{2}$ From Bittante et al., 2014b: milk samples from ewes of local breeds of the Veneto region reared for lamb production.

${ }^{3}$ From Bittante et al., 2014a: milk samples from Brown Swiss cows. 
Table 2. Descriptive statistics (least squares means $\pm \mathrm{SD}$ ) of quality traits of Sarda ewe milk samples according to their type of curd-firming modeling ${ }^{1}$

\begin{tabular}{|c|c|c|c|c|c|}
\hline Item & $\begin{array}{c}\text { Not coagulated } \\
\text { samples }\end{array}$ & $\begin{array}{c}\text { Not converged } \\
\text { equations }\end{array}$ & \multicolumn{3}{|c|}{ Converged equations } \\
\hline Samples (no.) & 5 & 49 & 202 & 814 & 51 \\
\hline Daily milk yield (kg/d) & $1.51 \pm 0.45$ & $1.65 \pm 0.77$ & $1.51 \pm 0.81$ & $1.60 \pm 0.85$ & $1.79 \pm 0.88$ \\
\hline \multicolumn{6}{|l|}{ Milk contents } \\
\hline Fat $(\%)$ & $6.36 \pm 1.19$ & $6.65 \pm 1.20$ & $6.28 \pm 1.01$ & $6.47 \pm 1.23$ & $6.50 \pm 1.08$ \\
\hline Casein number (\%) & $73.9 \pm 1.9$ & $78.1 \pm 1.3$ & $78.2 \pm 2.1$ & $77.8 \pm 1.7$ & $78.1 \pm 1.2$ \\
\hline Lactose $(\%)$ & $3.37 \pm 0.85$ & $4.81 \pm 0.38$ & $4.87 \pm 0.29$ & $4.80 \pm 0.29$ & $4.78 \pm 0.35$ \\
\hline Urea $(\mathrm{mg} / \mathrm{mL})$ & $19.3 \pm 7.3$ & $32.6 \pm 10.1$ & $32.6 \pm 10.5$ & $32.0 \pm 11.3$ & $28.9 \pm 13.5$ \\
\hline $\mathrm{pH}$ & $7.07 \pm 0.23$ & $6.72 \pm 0.15$ & $6.65 \pm 0.09$ & $6.67 \pm 0.08$ & $6.69 \pm 0.12$ \\
\hline $\mathrm{SCS}^{2}$ (units) & $9.83 \pm 0.84$ & $5.07 \pm 2.51$ & $4.81 \pm 2.23$ & $4.63 \pm 2.04$ & $4.75 \pm 2.27$ \\
\hline $\mathrm{LBC}^{3}$ (units) & $3.20 \pm 1.38$ & $2.62 \pm 1.07$ & $2.39 \pm 0.79$ & $2.53 \pm 0.97$ & $3.00 \pm 0.99$ \\
\hline
\end{tabular}

${ }^{1}$ Not coagulated $=$ milk samples that did not coagulate within 60 min after rennet addition; not converged equations $=$ milk samples with $\mathrm{CF}$ data not converging according to the $\mathrm{CF}_{\mathrm{t}}$ model, usually because of late coagulation and a small number of observations $>0$; no- $\mathrm{k}_{\mathrm{SR}}=$ milk samples that did not show a phase of decreasing curd firmness within $60 \mathrm{~min}$ after the phase of increase because of syneresis; low-k $\mathrm{k}_{\mathrm{SR}}=$ milk samples characterized by a $\mathrm{k}_{\mathrm{SR}}<3 \% / \mathrm{min}$; and high- $\mathrm{k}_{\mathrm{SR}}=$ milk samples characterized by a $\mathrm{k}_{\mathrm{SR}}>3 \% / \mathrm{min}$.

${ }^{2} \mathrm{SCS}=\log _{2}\left(\mathrm{SCC} \times 10^{-5}\right)+3$.

${ }^{3} \mathrm{LBC}=\log _{10}$ of total bacterial count.

$(-7 \%)$ and $\mathrm{k}_{20}(-5 \%)$ values and lower $\mathrm{a}_{30}(-16 \%)$, $\mathrm{a}_{45}(-42 \%)$, and $\mathrm{a}_{60}(-60 \%)$ values. Moreover, the $\mathrm{CF}_{\mathrm{t}}$ equation parameters (Table 1 ) were quite different from the low- $\mathrm{k}_{\mathrm{SR}}$ group; the high- $\mathrm{k}_{\mathrm{SR}}$ samples were characterized by much greater $\mathrm{CF}_{\mathrm{P}}(+188 \%)$ and $\mathrm{k}_{\mathrm{SR}}(+404 \%)$ and a smaller $\mathrm{k}_{\mathrm{CF}}(-55 \%)$. The large differences in $\mathrm{CF}_{\mathrm{t}}$ parameters led to a small difference in $\mathrm{CF}_{\max }(+2 \%)$, because of a compensating pattern among the parameters and the anticipation of $t_{\max }(-15 \%$; Table 1$)$. In other papers, discrimination of the groups according to $\mathrm{k}_{\mathrm{SR}}$ has not been possible because of the low number of sampled ewes (Bittante et al., 2014), and in the case of cows (Bittante et al., 2015), because of the mono-modal distribution of $\mathrm{k}_{\mathrm{SR}}$ among the animals.

The majority of the Sarda ewes, 814 out of 1,121 $(72.6 \%)$, yielded low- $\mathrm{k}_{\mathrm{SR}}$ milk samples, which were characterized by $\mathrm{CF}_{\mathrm{t}}$ modeling parameters that were similar to those obtained by Bittante et al. (2014) from Alpine sheep breeds but were different from those of dairy cows. Indeed, if compared with samples from Brown Swiss cows reared in the Alps (Bittante et al., 2015) and Holstein and crossbred cows reared in intensive farms on the plains (Malchiodi et al., 2014), the ovine samples were characterized by a rapid gelation $\left(\mathrm{RCT}_{\mathrm{eq}}\right.$ : -52 and $-55 \%$, respectively, for the comparison with Brown Swiss and Holstein plus crossbred), a similar asymptotic potential $\mathrm{CF}\left(\mathrm{CF}_{\mathrm{P}}:+8\right.$ and $+21 \%$, respectively), a fast curd-firming rate $\left(\mathrm{k}_{\mathrm{CF}}:+131\right.$ and $+138 \%$, respectively), and a slow syneresis $\left(\mathrm{k}_{\mathrm{SR}}:-36 \%\right.$ for the comparison with Brown Swiss). In the paper on Holstein and crossbred cows, the reduced 3-parameter $\mathrm{CF}_{\mathrm{t}}$ model is applied, and the $\mathrm{k}_{\mathrm{SR}}$ is not available; moreover, the $\mathrm{CF}_{\mathrm{P}}$ parameter is slightly underestimated because it is not corrected for the effect of syneresis (Malchiodi et al., 2014).

The estimation of the $\mathrm{CF}_{\mathrm{t}}$ individual equation parameters created the $\mathrm{CF}_{\mathrm{t}}$ curve for each sample, and using the median parameters to avoid the effect on the means due to the non-Gaussian distribution of parameters, depicted the average curve for the 5 groups of samples (noncoagulating, not-converged, no- $\mathrm{k}_{\mathrm{SR}}$, low$\mathrm{k}_{\mathrm{SR}}$, and high- $\mathrm{k}_{\mathrm{SR}}$ ), which are represented in Figure 4. With the obvious exception of the few noncoagulating samples and the delay of coagulation of not-converged samples, the initial increase of the curves, up to approximately $15 \mathrm{~min}$ after rennet addition, was similar among the different groups. The comparison of the curves of the 2 most numerous groups (low- $\mathrm{k}_{\mathrm{SR}}$ and no$\mathrm{k}_{\mathrm{SR}}$ ) was particularly useful to understand the effect of syneresis. Indeed, these 2 main groups of samples were characterized by similar average values of $\mathrm{RCT}_{\mathrm{eq}}, \mathrm{CF}_{\mathrm{P}}$, and $\mathrm{k}_{\mathrm{CF}}$, whereas they were quite different on the basis of the value of $\mathrm{k}_{\mathrm{SR}}$ (Table 1 ). The syneresis negatively affected the measurement of CF because the divergence between the 2 groups began in the increasing part of the $\mathrm{CF}_{\mathrm{t}}$ curve. Indeed, no- $\mathrm{k}_{\mathrm{SR}}$ samples showed a progressively slower increase of $\mathrm{CF}$ toward the asymptotic $\mathrm{CF}_{\mathrm{P}}$ (theoretically at infinite time), whereas for low- $\mathrm{k}_{\mathrm{SR}}$ samples, approximately $25 \mathrm{~min}$ after rennet addition $\left(t_{\max }\right)$, the negative effect of $\mathrm{k}_{\mathrm{SR}}$ counterbalanced the positive effect of $\mathrm{k}_{\mathrm{CF}}$ and the sample reached the $\mathrm{CF}_{\max }$. Immediately after $\mathrm{t}_{\max }$, the $\mathrm{k}_{\mathrm{SR}}$ prevailed and the $\mathrm{CF}$ diminished toward an asymptotic null value at infinite time. 

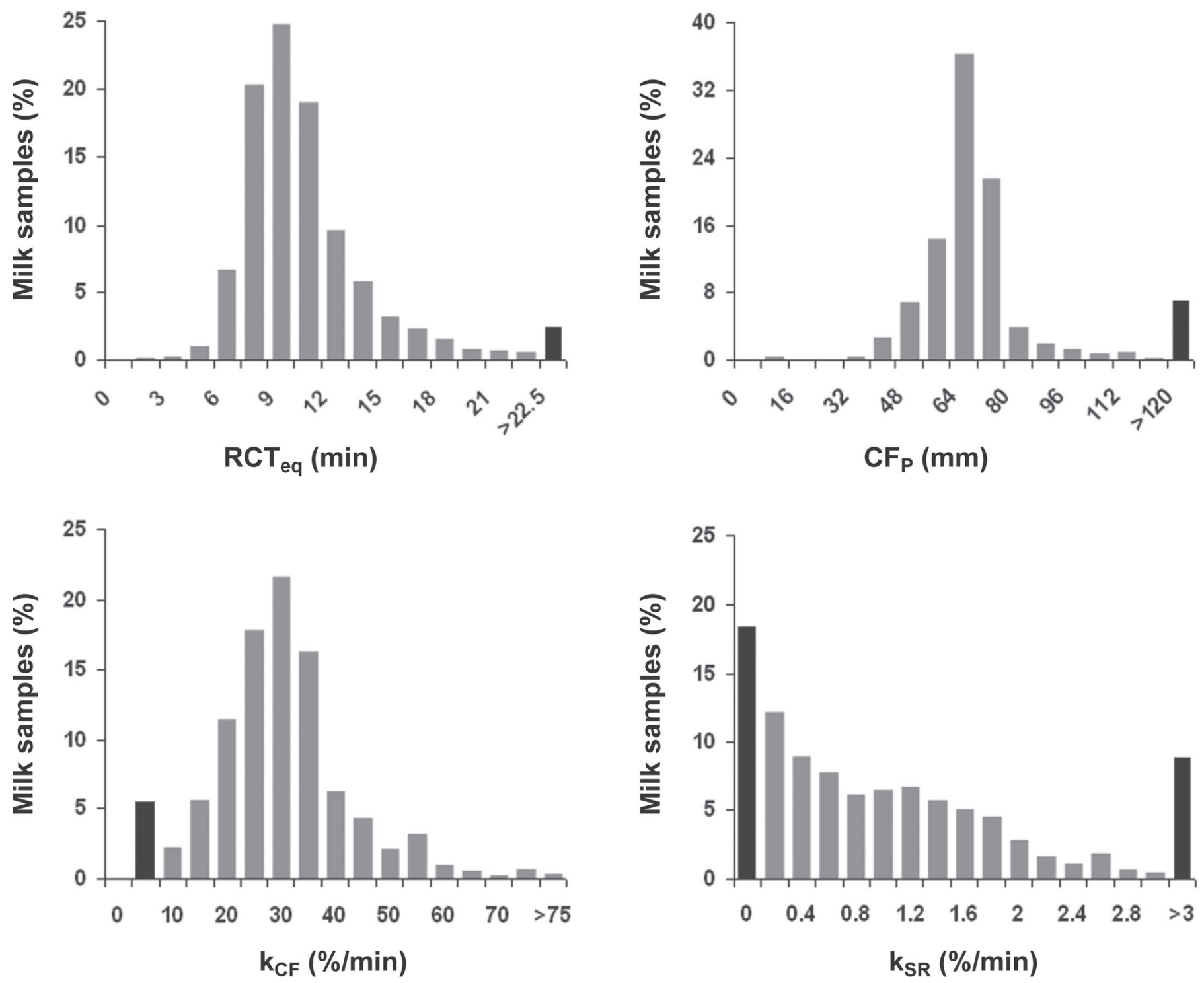

Figure 2. Distribution of the parameters of the individual curd-firming equations $\left(\mathrm{RCT}_{\mathrm{eq}}=\right.$ rennet coagulation time; $\mathrm{CF}_{\mathrm{P}}=$ asymptotical curd firmness; $\mathrm{k}_{\mathrm{CF}}=$ instant curd firming rate constant; and $\mathrm{k}_{\mathrm{SR}}=$ instant syneresis rate constant) of 1,121 milk samples of Sarda ewes (black bars indicate extreme values: for $\mathrm{RCT}$ values $>22.5 \mathrm{~min}$; for $\mathrm{CF}_{\mathrm{p}}$ values $>120 \mathrm{~mm}$; for $\mathrm{k}_{\mathrm{CF}}$ values $<5 \% / \mathrm{min}$; for $\mathrm{k}_{\mathrm{SR}}$ values $=0 \% / \mathrm{min}$ on the left and $>3 \% / \mathrm{min}$ on the right).

The decrease of the $\mathrm{CF}$ value for low- $\mathrm{k}_{\mathrm{SR}}$ samples during the lactodynamographic analysis was not interpreted as an actual reduction of curd firmness. In fact, upon reaching the gel formation that corresponded to $\mathrm{RCT}$, in a few seconds, milk samples changed physical status from liquid phase to gel phase, independently of their $\mathrm{k}_{\mathrm{SR}}$ group. After gelation, milk samples underwent a progressive firming of the gel, and with large variability among samples, a syneresis process characterized by the curd contraction and the expelling of a growing proportion of whey, which was mainly located between the curd itself and the internal surface of the small vat used for the test. Starting from this stage, 2 dis- tinct phases, the liquid whey and the solid curd, were distinguishable in the small vat of low- $\mathrm{k}_{\mathrm{SR}}$ samples. Consequently, during oscillation of the lactodynamographic apparatus, the curd floated in the whey and the pendulum inserted within the curd recorded a lower resistance, and as a result, a lower $\mathrm{CF}$ value. It could be that the actual firmness of the curd of the low- $\mathrm{k}_{\mathrm{SR}}$ samples continued to increase toward the $\mathrm{CF}_{\mathrm{P}}$ value, as happened for the no- $\mathrm{k}_{\mathrm{SR}}$ samples, even if the apparatus registered decreasing resistance.

For the 2 remaining groups of samples shown in Figure 4 , the high- $\mathrm{k}_{\mathrm{SR}}$ samples had a curve similar to the low- $\mathrm{k}_{\mathrm{SR}}$ samples during the initial increase phase but a 



Figure 3. Distribution of the traits derived from the curd-firming model $\left(\mathrm{CF}_{\max }=\right.$ maximum curd firmness and $t_{\max }=$ time from rennet addition to the attainment of the $\mathrm{CF}_{\max }$ ) of 1,121 Sarda ewes (black bars indicate samples with $\mathrm{t}_{\max }>55 \mathrm{~min}$ ).



Figure 4. Trends of curd firmness recorded after rennet addition obtained using the median parameters of individual equations (1,121 Sarda ewes) according to the different models of curd-firming $\left[n o-k_{\mathrm{SR}}=\right.$ milk samples that did not show a phase of decreasing curd firmness within 60 min after the phase of increase because of syneresis; low- $\mathrm{k}_{\mathrm{SR}}=$ milk samples characterized by a $\mathrm{k}_{\mathrm{SR}}<3 \% / \mathrm{min}$; high- $\mathrm{k}_{\mathrm{SR}}=$ milk samples characterized by a $\mathrm{k}_{\mathrm{SR}}>3 \% / \mathrm{min}$; and not converged: milk samples with curd-firming data not converging according to the curd-firming over time $\left(\mathrm{CF}_{\mathrm{t}}\right)$ model, usually because of late coagulation and a small number of observations $>0$; not coagulated: milk samples that did not coagulate within 60 min after rennet addition]. 
more rapid decrease thereafter, and the nonconvergent samples had a curve similar in shape to the high- $\mathrm{k}_{\mathrm{SR}}$ one but the increase was delayed for some minutes and thus reached a smaller $\mathrm{CF}_{\max }$, and particularly, $\mathrm{t}_{\max }$.

The traditional MCP recorded within 30 min were not able to detect any appreciable differences among the 4 groups of coagulated samples (Table 1), with the only exception being the later and variable coagulation time of samples with not-converged equations. Moreover, in the case of ovine milk, the $\mathrm{a}_{30}$ measured the $\mathrm{CF}$ after $t_{\max }$ in the decreasing part of the $\mathrm{CF}_{\mathrm{t}}$ curve, with the only exception being the no- $\mathrm{k}_{\mathrm{SR}}$ samples. With the exception of this last group of samples, the sole investigation of $\mathrm{a}_{30}$ caused a large underestimation of $\mathrm{CF}_{\max }$ and $\mathrm{CF}_{\mathrm{P}}$ of sheep milk, and this was particularly evident for the high- $\mathrm{k}_{\mathrm{SR}}$ samples.

It should also be emphasized that the 4 groups of samples were characterized by approximately similar milk quality traits and were produced by ewes of similar lactation stage and milk yield (Table 2). Therefore, neither the composition of milk nor the traditional measures of MCP can be used as reliable parameters to predict the pattern of coagulation and curd-firming, and especially, syneresis of sheep milk (Cecchinato, 2013).

\section{Effect of Flock Size and Individual Flock}

Large individual variability was also found within each group of samples. To analyze the sources of variation of the individual equation parameters, an ANOVA was applied after the exclusion of "extreme" samples that had a $\mathrm{CF}_{\mathrm{P}}>120 \mathrm{~mm}$ from the data set. The excluded samples consisted of all of the not-converged and the majority of the high- $\mathrm{k}_{\mathrm{SR}}$ samples.

Results for this analysis are summarized in Table 3. The incidence of milk samples that showed syneresis $\left(\mathrm{k}_{\mathrm{SR}}>0\right)$, and consequently $\mathrm{CF}_{\max }$ and $\mathrm{t}_{\max }$, was affected by the flock size. In particular, the farms with 300 to 600 ewes were characterized by a lower incidence of syneretic milk samples, longer $t_{\max }$, and greater $\mathrm{CF}_{\max }$ (Figure 5) than milk samples from farms with smaller or greater flocks. It is worth mentioning (Pazzola et al., 2014a) that the intermediate farms were mainly in hilly areas of Sardinia (the largest were in the plains and the smallest were in the hills and mountains), were family operated (similar to smaller farms), and almost all were characterized by cultivated grassland and rotational pasture and with control of the lambing season (the smallest farms frequently adopted free-range pasture in natural grasslands, and the largest ones used rotational pasture coupled with total mixed rations, modern buildings and facilities, and the advice of consultants and experts in sheep nutrition). An in- direct confirmation of the effect of flock size on curd syneresis is found in a previous study on traditional MCP (Pazzola et al., 2014a), where milk samples from intermediate farms are characterized by a greater single point $\mathrm{CF}$ measured $30(+19 \%), 45(+27 \%)$, and 60 $(+28 \%)$ min after rennet addition. Based on the results of the present study, it seemed clear that the differences among farming systems measured through traditional $\mathrm{a}_{30}, \mathrm{a}_{45}$, and $\mathrm{a}_{60}$ were not related to actual differences in the curd-firming process (similar $\mathrm{CF}_{\mathrm{P}}$ and $\mathrm{k}_{\mathrm{CF}}$ ) but were related to curd syneresis. Some literature has addressed the effects of feeding and management strategy on coagulation properties of milk from small ruminants (Abilleira et al., 2010; Pazzola et al., 2011; Inglingstad et al., 2014), but they were conducted primarily under experimental conditions.

Flock/test date within flock size was an important source of variation of the model parameters, in accordance with the results regarding traditional MCP of sheep milk (Pazzola et al., 2014a). Indeed, the flock/ test date represented 17 to $23 \%$ of the total variance for all model parameters and derived traits, respectively, with 2 exceptions: the incidence of syneretic samples $\left(\mathrm{k}_{\mathrm{SR}}>0\right)$, which was less influenced by individual farms (11\% of total variance), and $\mathrm{CF}_{\max }$, which was more highly affected (43\%). This last trait was the result of the effects of all of the model parameters and was affected by flock/test date with a percentage slightly greater than the one found for $\mathrm{a}_{30}(38 \%)$, among the traditional MCP. In the case of bovine species, the herd effect is less important than for ovine species (Tyrisevä et al., 2003; Ikonen et al., 2004; Bittante et al., 2012).

\section{Effects of Lactation Stage, Parity, and Milk Yield}

For the sources of variation of the individual animals, the effect of the stage of lactation measured as DIM affected all of the model parameters and the $\mathrm{CF}_{\max }$, whereas parity affected the $\mathrm{RCT}_{\text {eq }}, \mathrm{CF}_{\max }$, and $\mathrm{k}_{\mathrm{SR}}$, and milk yield affected the $\mathrm{RCT}_{\mathrm{eq}}$ and $\mathrm{CF}_{\max }$ (Table 3).

For the effect of DIM, a quadratic trend caused the lowest values of $\mathrm{RCT}_{\mathrm{eq}}$ and $\mathrm{k}_{\mathrm{SR}}$, and the highest $\mathrm{k}_{\mathrm{CF}}$ was reached at mid-lactation (Figure 6). The $\mathrm{CF}_{\mathrm{P}}$ showed a linear increase through lactation and the $\mathrm{CF}_{\max }$, as a combined effect of all of the model parameters, showed a significant linear and quadratic trend with a rapid increase during the first part of lactation and stabilization in the second part. The incidence of syneretic samples and the $t_{\max }$ were not affected by DIM. Similar to the present study, the traditional MCP measured on the same samples show more favorable values of RCT and $\mathrm{k}_{20}$ at mid-lactation, whereas $\mathrm{a}_{30}$ and $\mathrm{a}_{45}$ but not $\mathrm{a}_{60}$ grow linearly during lactation (Pazzola et al., 2014a). These results are in accordance with other studies that 
Table 3. The results from ANOVA ( $F$-values for fixed factors and their contrasts, variance ratio for random factor) for curd-firming model parameters, and incidence of samples showing syneresis and maximum curd firmness from coagulated milk samples of Sarda ewes $\left(1,039 \text { samples with } \mathrm{CF}_{\mathrm{P}}<120 \mathrm{~mm}\right)^{1}$

\begin{tabular}{|c|c|c|c|c|c|c|c|c|}
\hline \multirow[b]{2}{*}{ Item } & \multirow[b]{2}{*}{$\mathrm{df}$} & \multicolumn{4}{|c|}{ Curd-firming model parameter } & \multirow{2}{*}{$\begin{array}{c}\begin{array}{c}\text { Syneretic } \\
\text { samples }\end{array} \\
\begin{array}{c}\mathrm{k}_{\mathrm{SR}}>0 \\
(\%)\end{array}\end{array}$} & \multicolumn{2}{|c|}{ Maximum curd firmness } \\
\hline & & $\begin{array}{l}\mathrm{RCT}_{\mathrm{eq}} \\
(\mathrm{min})\end{array}$ & $\begin{array}{c}\mathrm{CF}_{\mathrm{P}} \\
(\mathrm{mm})\end{array}$ & $\frac{\mathrm{k}_{\mathrm{CF}}}{(\% / \mathrm{min})}$ & $\begin{array}{c}\mathrm{k}_{\mathrm{SR}} \\
(\% / \mathrm{min})\end{array}$ & & $\begin{array}{l}\mathrm{CF}_{\max } \\
(\mathrm{mm})\end{array}$ & $\begin{array}{c}\mathrm{t}_{\max } \\
(\min )\end{array}$ \\
\hline Flock size ( $F$-value $)$ & 2 & 0.73 & 0.81 & 2.37 & 1.85 & $6.91^{* * *}$ & 3.11 & $7.27^{* * *}$ \\
\hline$<300$ vs. $>600$ ewes & 1 & 0.00 & 0.14 & 0.14 & 0.96 & 1.29 & 0.00 & 0.93 \\
\hline $300-600$ vs. $(<300+>600) / 2$ & 1 & 1.46 & 1.48 & $4.61^{*}$ & 2.71 & $12.42^{* *}$ & $6.22^{*}$ & $13.55^{* *}$ \\
\hline Flock/test day ${ }^{2}$ & 20 & 0.23 & 0.19 & 0.17 & 0.16 & 0.11 & 0.43 & 0.21 \\
\hline DIM ( $F$-value $)$ & 7 & $2.18^{*}$ & 1.30 & 1.43 & 1.64 & 0.83 & 1.89 & 0.46 \\
\hline Linear & 1 & 1.98 & $3.58^{*}$ & 0.02 & 0.21 & 1.10 & $6.26^{*}$ & 0.02 \\
\hline Quadratic & 1 & $8.73^{* *}$ & 1.01 & $6.56^{* *}$ & $3.68^{*}$ & 0.56 & $4.82^{*}$ & 0.72 \\
\hline Cubic & 1 & 0.12 & 0.06 & 0.85 & 0.03 & 0.61 & 0.07 & 2.30 \\
\hline Parity ( $F$-value) & 4 & $4.43^{* *}$ & 1.98 & 0.27 & 1.92 & 1.11 & $3.30^{* *}$ & 0.95 \\
\hline 1 vs. $2,3,4,5$ & 1 & $10.01^{* * *}$ & 2.56 & 0.04 & 1.80 & 2.91 & $11.30^{* * *}$ & 2.38 \\
\hline 2 vs. $3,4,5$ & 1 & $7.03^{* *}$ & 0.02 & 0.55 & 0.34 & 1.11 & 0.81 & 1.51 \\
\hline 3 vs. 4,5 & 1 & $5.99^{*}$ & 3.51 & 0.11 & $6.34^{*}$ & 0.03 & 0.19 & 0.10 \\
\hline 4 vs. 5 & 1 & 1.28 & 0.39 & 0.26 & 1.03 & 0.71 & 1.76 & 0.00 \\
\hline Milk yield ( $F$-value) & 6 & $2.61^{*}$ & 0.88 & 0.64 & 0.99 & 0.30 & $2.97^{* *}$ & 0.77 \\
\hline Linear & 1 & $9.93^{* *}$ & 0.59 & 1.49 & 2.27 & 0.65 & $8.67^{* *}$ & 2.85 \\
\hline Quadratic & 1 & 0.58 & 1.47 & 1.05 & 2.23 & 0.01 & 3.51 & 0.13 \\
\hline Cubic & 1 & 0.39 & 0.75 & 0.03 & 0.02 & 1.06 & 0.15 & 1.27 \\
\hline Pendulum ( $F$-value) & 9 & 0.86 & $8.74^{* * *}$ & 1.84 & $3.74^{* * *}$ & $4.78^{* * *}$ & $25.66^{* * *}$ & $3.65^{* * *}$ \\
\hline $\mathrm{RMSE}^{3}$ & 1,060 & 2.65 & 12.17 & 9.83 & 0.80 & 35.11 & 6.42 & 8.75 \\
\hline
\end{tabular}

$\subsetneq \overline{{ }^{1}} \mathrm{RCT}_{\mathrm{eq}}=$ rennet coagulation time obtained from the model; $\mathrm{CF}_{\mathrm{P}}=$ asymptotical curd firmness; $\mathrm{k}_{\mathrm{CF}}=$ instant curd firming rate constant; $\mathrm{k}_{\mathrm{SR}}=$ instant syneresis rate constant;

$\mathrm{CF}_{\max }=$ maximum curd firmness; and $\mathrm{t}_{\max }=$ time from rennet addition to the attainment of the $\mathrm{CF}_{\max }$.

O ${ }^{2}$ Flock/test day effect expressed as proportion of variance explained by flock/test date on the total variance.

ㄱ. ${ }^{3} \mathrm{RMSE}=$ root mean square error

$\stackrel{M}{*} \quad * P<0.05, * * P<0.01$, and ${ }^{* * *} P<0.001$. 
have measured traditional RCT of sheep milk throughout the different stages of lactation (Pugliese et al., 2000; Sevi et al., 2000; Pazzola et al., 2013). Overall, the decrease in protein and casein contents, which is commonly recorded during the middle stages of lactation (Jaeggi et al., 2005), could have significantly affected the pattern of traditional RCT. Indeed, the concentration of the rennet enzyme, which is necessary to coagulate casein, is directly proportional to the concentration of the casein itself (Dalgleish, 1981; Bencini, 2002), and the lower the content of casein is the faster the gel formation and RCT should be. The simultaneous recording of $\mathrm{CF}_{\max }$ zenith during the middle stages of lactation was in accordance with data obtained for $\mathrm{a}_{30}$ (Sevi et al., 2000; Pazzola et al., 2013), as an earlier $\mathrm{RCT}_{\mathrm{eq}}$ allowed for a greater distance between the arms of the bifurcation in the graphic representation of traditional MCP (McMahon and Brown, 1982), and as a consequence, a greater value of curd firmness, when syneresis was not very important.

The patterns of coagulation, syneresis, and maximum curd firmness according to the different levels of parity are illustrated in Figure 7. The coagulation time was longer for the mature ewes than the young ewes (at least until fourth parity), and the rate of syneresis increased within adult animals moving from the third to the fourth and greater parities. Last, $\mathrm{CF}_{\max }$ was greater for primiparous than pluriparous ewes. These results are consistent with data regarding traditional single-point curd firmness obtained by Pugliese et al. (2000) and Pazzola et al. (2014a) but not by Jaramillo et al. (2008).

The milk yield was not an important source of variation for coagulation, curd-firming, or syneresis or for derived traits and it affected only $\mathrm{RCT}_{\text {eq }}$ and $\mathrm{CF}_{\max }$ (Table 3). The $\mathrm{RCT}_{\text {eq }}$ decreased and $\mathrm{CF}_{\max }$ increased linearly with the increase in milk yields (Figure 8). In the case of traditional MCP, milk yield affected all traits linearly, except $\mathrm{a}_{45}$, and in the cases of $\mathrm{k}_{20}$ and $\mathrm{a}_{30}$, the quadratic term was also significant (Pazzola et al., 2014a), and caused the major part of variation to be during the first rather than the second part of lactation. For a correct evaluation of these results, it should be noted that the model in the present study included flock size, individual flock, DIM, and parity of ewes, so the effect of milk yield was not affected by structural and management features or by differences in age and lactation stage of the animals.

Additionally, the position of the individual pendulum within the 10 available measuring units of the coagulation meter significantly affected the estimated $\mathrm{CF}_{\mathrm{t}}$ parameters and their derived traits $\left(\mathrm{CF}_{\max }\right.$ and $\left.\mathrm{t}_{\max }\right)$, and this was in accordance with what has been observed for traditional MCP (Pazzola et al., 2014a) and confirmed
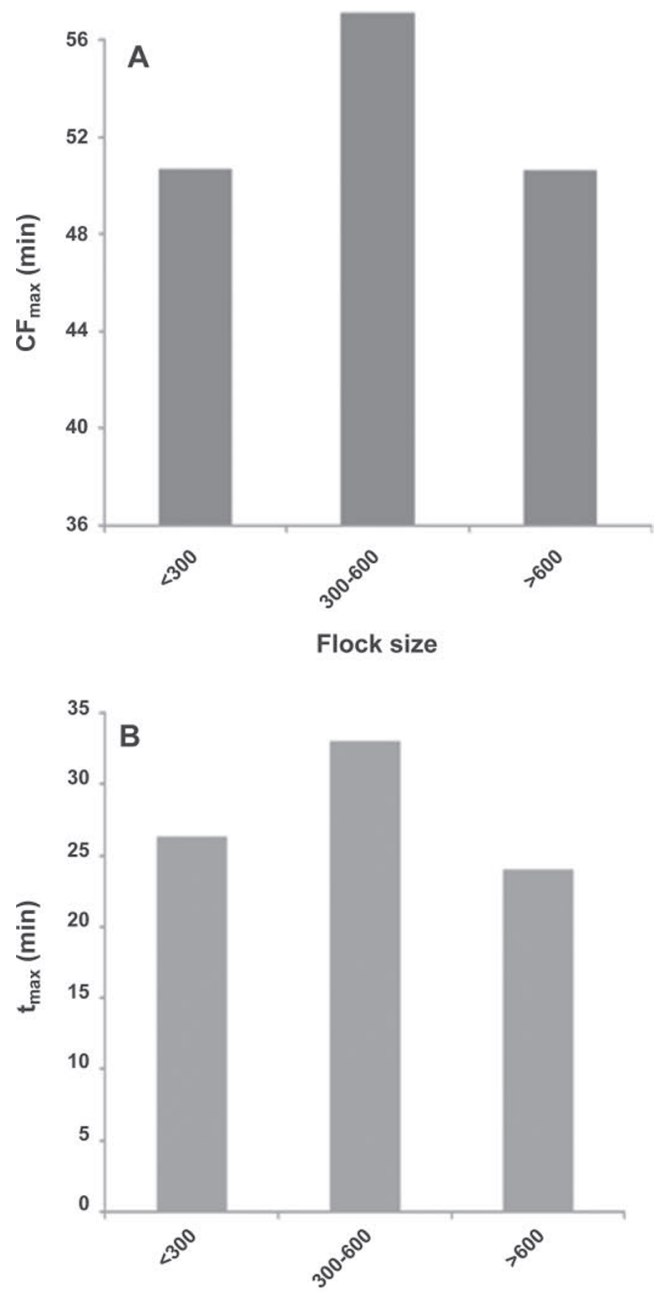

Flock size

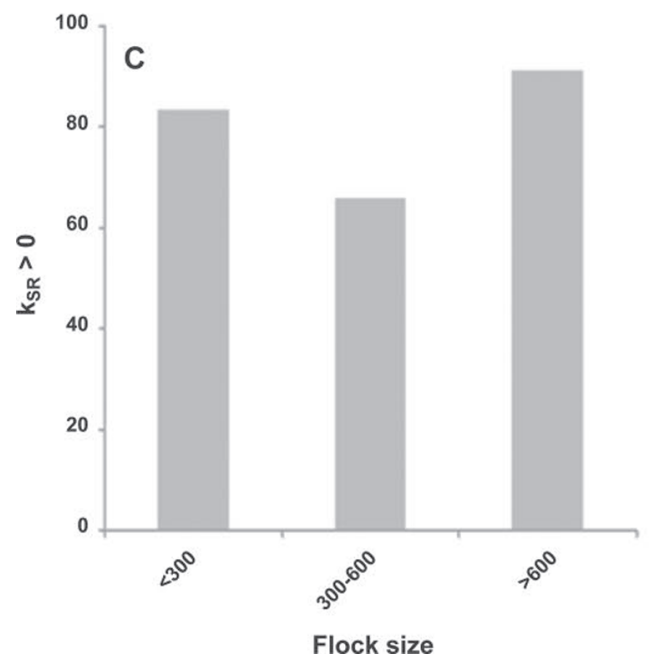

Figure 5. Effect of dairy sheep farming systems characterized by different flock size on traits derived by the curd-firming over time $\left(\mathrm{CF}_{\mathrm{t}}\right)$ model $\left(\mathrm{CF}_{\max }=\right.$ maximum curd firmness and $\mathrm{t}_{\max }=$ time after rennet addition of attaining of $\mathrm{CF}_{\max }$ ) and on incidence of ewes with milk that exhibited a decreasing phase of curd firmness after the increasing one because of syneresis $\left(\mathrm{CF}_{\mathrm{t}}\right.$ models with $\left.\mathrm{k}_{\mathrm{SR}}>0\right)$. 

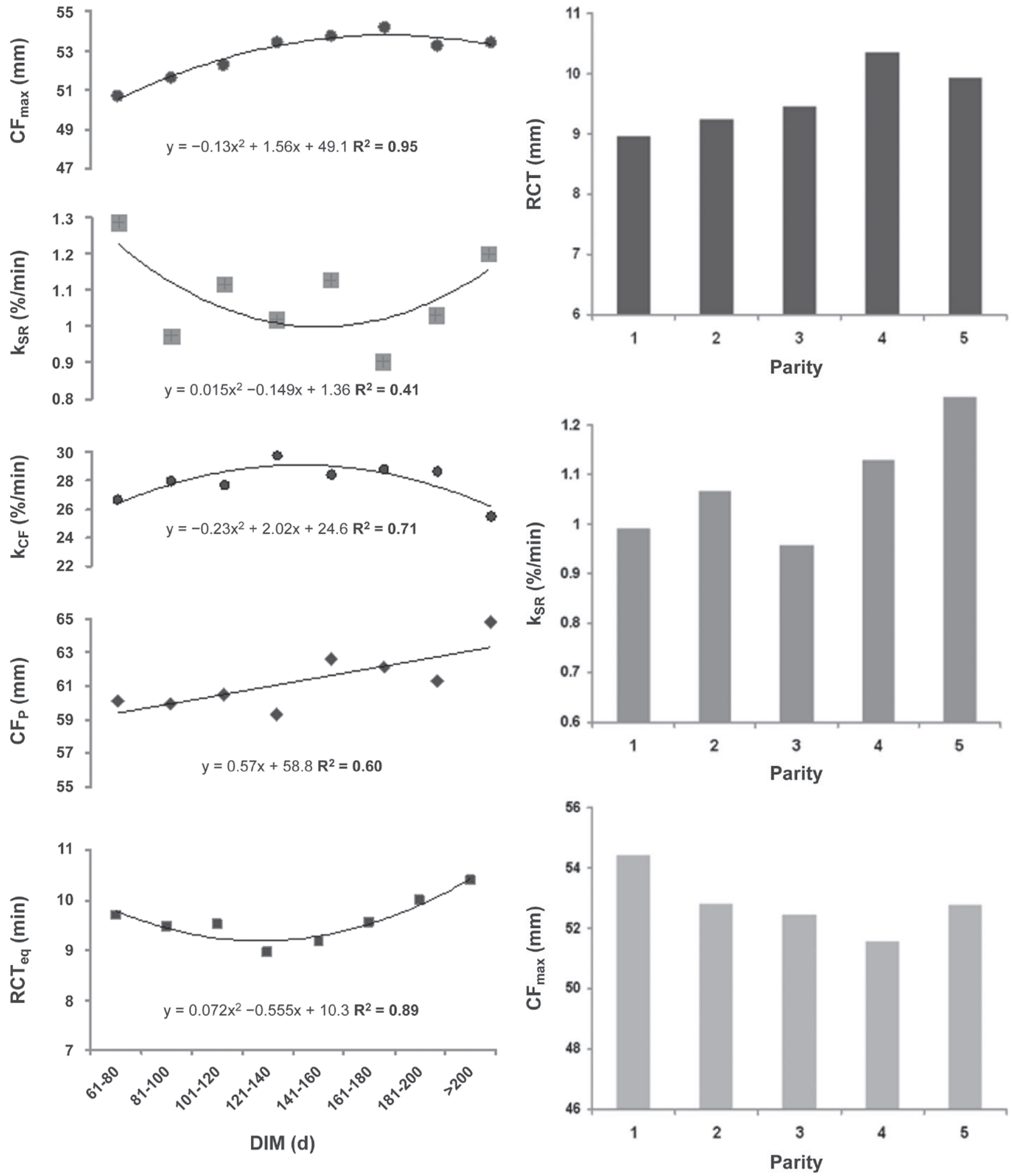

Figure 6. Effect of DIM on maximum curd firmness $\left(\mathrm{CF}_{\max }, \mathrm{mm}\right)$, curd syneresis instant rate constant $\left(\mathrm{k}_{\mathrm{SR}}, \% / \mathrm{min}\right)$, curd-firming instant rate constant $\left(\mathrm{k}_{\mathrm{CF}}, \% / \mathrm{min}\right)$, asymptotic potential curd firmness $\left(\mathrm{CF}_{\mathrm{P}}\right.$, $\mathrm{mm})$, and rennet coagulation time $\left(\mathrm{RCT}_{\mathrm{eq}}, \mathrm{min}\right)$, estimated on the basis of the curd-firming over time $\left(\mathrm{CF}_{\mathrm{t}}\right)$ model.

Figure 7. Effect of parity on rennet coagulation time $\left(\mathrm{RCT}_{\text {eq }}\right.$, $\min )$, on syneresis instant rate constant $\left(\mathrm{k}_{\mathrm{SR}}, \% / \mathrm{min}\right)$, and on maximum curd firmness $\left(\mathrm{CF}_{\max }, \mathrm{mm}\right)$ estimated based on the curd-firming over time $\left(\mathrm{CF}_{\mathrm{t}}\right)$ model. 

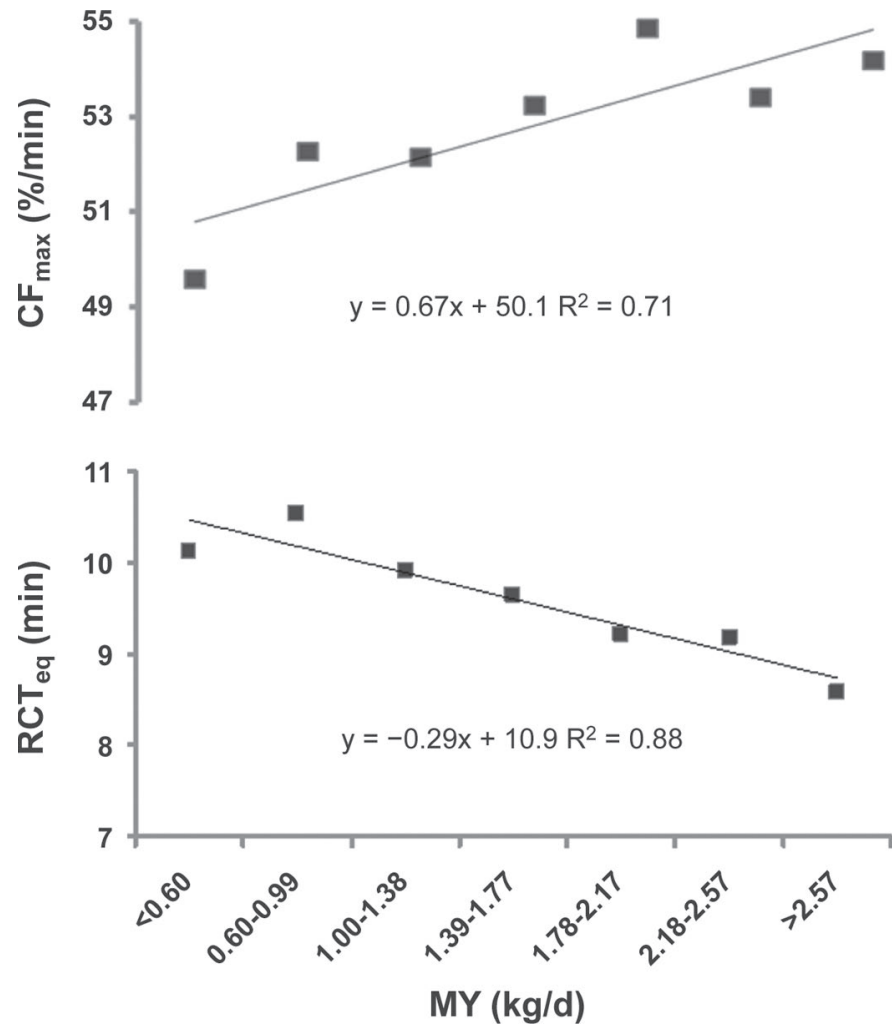

Figure 8. Effect of daily milk yield on maximum curd firmness $\left(\mathrm{CF}_{\max }, \mathrm{mm}\right)$ and rennet coagulation time $\left(\mathrm{RCT}_{\text {eq }}, \mathrm{min}\right)$ estimated based on the curd-firming over time $\left(\mathrm{CF}_{\mathrm{t}}\right)$ model.

the need for the inclusion of this source of variation in the statistical model.

\section{CONCLUSIONS}

In conclusion, the results from present study showed that the extension of the lactodynamographic test up to 60 min provided a suitable tool to achieve a deeper interpretation of coagulation properties of sheep milk. In particular, the parameters obtained from the modeling of the $\mathrm{CF}_{\mathrm{t}}$ curve demonstrated that the sole investigation of the traditional MCP and the 30 min analysis led to a misleading interpretation of the actual processes of milk coagulation, curd-firming, and syneresis. Furthermore, the investigation and modeling of curd firmness based on the 240 point observations available for each sample provided a useful classification of milk according to the $\mathrm{CF}_{\mathrm{t}}$ parameters. Different from the bovine species, the ovine species is characterized by variable numbers of ewes that produce milk that does not show any sign of syneresis or a high syneresis rate. Sources of variation were also investigated, with the flock, DIM, parity, milk yield, and the individual pendulum of the instrument as the main factors affecting the model parameters. The incidence of syneretic samples was affected by management practices and structural differences such as flock size but not much by individual farms within class of flock size, parity, lactation stage, or milk productivity within farm. Given the larger variability observed for coagulation, firming, and syneresis traits in ovine milk than with bovine milk, it will be interesting to study the genetic basis and parameters of these traits.

\section{ACKNOWLEDGMENTS}

This research was supported by a grant from the Fondazione Banco di Sardegna (Bank of Sardinia Foundation). The authors thank the farmers for giving access to their flocks, the AIPA/APAs (Provincial Farmers Associations) of Cagliari, Nuoro, Sassari, and Oristano for their support in sample collection, and A. R. A. Sardegna (Regional Farmer Association of Sardinia) for support in milk analysis. We also thank American Journal Experts for English language editing.

\section{REFERENCES}

Abilleira, E., M. Virto, A. I. Nájera, J. Salmerón, M. Albisu, F. J. Pérez-Elortondo, J. C. Ruiz de Gordoa, M. de Renobales, and J. R. Barron. 2010. Effects of seasonal changes in feeding management under part-time grazing on the evolution of the composition and coagulation properties of raw milk from ewes. J. Dairy Sci. 93:3902-3909.

Auldist, M. J., K. A. Johnston, N. J. White, W. P. Fitzsimons, and M. J. Boland. 2004. A comparison of the composition, coagulation characteristics and cheesemaking capacity of milk from Friesian and Jersey dairy cows. J. Dairy Res. 71:51-57.

Bencini, R. 2002. Factors affecting the clotting properties of sheep milk. J. Sci. Food Agric. 82:705-719.

Bittante, G. 2011. Modeling rennet coagulation time and curd firmness of milk. J. Dairy Sci. 94:5821-5832.

Bittante, G., C. Cipolat-Gotet, F. Malchiodi, E. Sturaro, F. Tagliapietra, S. Schiavon, and A. Cecchinato. 2015. Effect of dairy farming system, herd, season, parity and days in milk on modeling of coagulation, curd firming and syneresis of bovine milk. J. Dairy Sci. 98:2759-2774. http://dx.doi.org/10.3168/jds.2014-8909.

Bittante, G., B. Contiero, and A. Cecchinato. 2013. Prolonged observation and modelling of milk coagulation, curd firming, and syneresis. Int. Dairy J. 29:115-123.

Bittante, G., E. Pellattiero, F. Malchiodi, C. Cipolat-Gotet, M. Pazzola, G. M. Vacca, S. Schiavon, and A. Cecchinato. 2014. Quality traits and modelling of coagulation, curd firming and syneresis of sheep milk of Alpine breeds fed diets supplemented with rumenprotected conjugated fatty acid. J. Dairy Sci. 97:4018-4028.

Bittante, G., M. Penasa, and A. Cecchinato. 2012. Invited review: Genetics and modeling of milk coagulation properties. J. Dairy Sci. 95:6843-6870.

Calvo, M. M., and E. Balcones. 2000. Some factors influencing the syneresis of bovine, ovine and caprine milks. J. Dairy Sci. 83:17331739

Carcangiu, V., M. C. Mura, G. M. Vacca, M. L. Dettori, M. Pazzola, S. Luridiana, and P. P. Bini. 2011. Improvement of the reproductive efficiency for the development of the Sardinian sheep breeding. Pages 82-88 in New Trends for Innovation in the Mediterranean Animal Production, EAAP Scientific Series 129. R. Bouche, A. Derkimba, and F. Casabianaca, ed. Wageningen Academic Publishers, Wageningen, the Netherlands. 
Carta, A., S. Casu, and S. Salaris. 2009. Invited review: Current state of genetic improvement in dairy sheep. J. Dairy Sci. 92:58145833 .

Cecchinato, A. 2013. Survival analysis as a statistical methodology for analyzing factors that affect milk coagulation time in HolsteinFriesian and Brown Swiss cows. J. Dairy Sci. 96:5556-5564.

Cecchinato, A., M. Penasa, M. De Marchi, L. Gallo, G. Bittante, and P. Carnier. 2011. Genetic parameters of coagulation properties, milk yield, quality, and acidity estimated using coagulating and noncoagulating milk information in Brown Swiss and HolsteinFriesian cows. J. Dairy Sci. 94:4205-4213.

Cipolat-Gotet, C., A. Cecchinato, M. De Marchi, M. Penasa, and G. Bittante. 2012. Comparison between mechanical and near-infrared methods for assessing coagulation properties of bovine milk. J. Dairy Sci. 95:6806-6819.

Claeys, W. L., C. Verraes, S. Cardoen, J. De Block, A. Huyghebaert, K. Raes, K. Dewettinck, and L. Herman. 2014. Consumption of raw or heated milk from different species: An evaluation of the nutritional and potential health benefits. Food Contr. 42:188-201.

Dalgleish, D. G. 1981. Effect of milk coagulation on the nature of curd formed during renneting - A theoretical discussion. J. Dairy Res. 48:65-69.

Devold, T. G., R. Nordbø, T. Langsrud, C. Svenning, M. J. Brovold, E. S. Sørensen, B. Christensen, T. Adnøy, and G. E. Vegarud. 2010. Extreme frequencies of the as1-casein 'null' variant in milk from Norwegian dairy goats-implications for milk composition, micellar size and renneting properties. Dairy Sci. Technol. 91:39-51.

FAOSTAT. 2014. Statistical Database of the Food and Agriculture Organization of the United Nations. Accessed Jun. 13, 2014. http:// faostat.fao.org/.

Ikonen, T., K. Ahlfors, R. Kempe, M. Ojala, and O. Ruottinen. 1999 Genetic parameters for the milk coagulation properties and prevalence of noncoagulating milk in Finnish dairy cows. J. Dairy Sci. 82:205-214.

Ikonen, T., S. Morri, A.-M. Tyrisevä, O. Ruottinen, and M. Ojala. 2004. Genetic and phenotypic correlations between milk coagulation properties, milk production traits, somatic cell count, casein content, and pH of milk. J. Dairy Sci. 87:458-467.

Inglingstad, R. A., H. Steinshamn, B. S. Dagnachew, B. Valenti, A. Criscione, E. O. Rukke, T. G. Devold, S. B. Skeie, and G. E. Vegarud. 2014. Grazing season and forage type influence goat milk composition and rennet coagulation properties. J. Dairy Sci. 97:3800-3814

Jaeggi, J. J., W. L. Wendorff, J. Romero, Y. M. Berger, and M. E. Johnson. 2005. Impact of seasonal changes in ovine milk on composition and yield of a hard-pressed cheese. J. Dairy Sci. 88:13581363.

Jaramillo, D. P., A. Zamora, B. Guamis, M. Rodrìguez, and A. J. Trujillo. 2008. Cheesemaking aptitude of two Spanish dairy ewe breeds: Changes during lactation and relationship between physico-chemical and technological properties. Small Rumin. Res. 78:48-55.

Malacarne, M., A. Summer, E. Fossa, P. Formaggioni, P. Franceschi, M. Pecorari, and P. Mariani. 2006. Composition, coagulation properties and Parmigiano-Reggiano cheese yield of Italian Brown and Italian Friesian herd milks. J. Dairy Res. 73:171-177.

Malchiodi, F., A. Cecchinato, M. Penasa, C. Cipolat-Gotet, and G Bittante. 2014. Milk quality, coagulation properties, and curd firmness modeling of purebred Holsteins and first- and secondgeneration crossbred cows from Swedish Red, Montbéliarde, and Brown Swiss bulls. J. Dairy Sci. 97:4530-4541.

McMahon, D. J., and R. J. Brown. 1982. Evaluation of Formagraph for comparing rennet solutions. J. Dairy Sci. 65:1639-1642.
Merin, U., N. Silanikove, F. Shapiro, S. Bernstein, and G. Leitner. 2004. Changes in milk composition as affected by subclinical mastitis in sheep and goats. S. Afr. J. Anim. Sci. 34:188-191.

Mura, M. C., C. Daga, M. Paludo, S. Luridiana, M. Pazzola, S. Bodano, M. L. Dettori, G. M. Vacca, and V. Carcangiu. 2012. Analysis of polymorphism within POU1F1 gene in relation to milk production traits in dairy Sarda sheep breed. Mol. Biol. Rep. 39:6975-6979.

Pazzola, M., F. Balia, V. Carcangiu, M. L. Dettori, G. Piras, and G. M. Vacca. 2012. Higher somatic cell counted by the electronic counter method do not influence renneting properties of goat milk. Small Rumin. Res. 102:32-36.

Pazzola, M., F. Balia, M. L. Dettori, M. C. Mura, V. Carcangiu, and G. M. Vacca. 2011. Effect of different storage conditions, the farm and the stage of lactation on renneting parameters of goat milk investigated using the Formagraph method. J. Dairy Res. 78:343348

Pazzola, M., M. L. Dettori, C. Cipolat-Gotet, A. Cecchinato, G. Bittante, and G. M. Vacca. 2014a. Phenotypic factors affecting coagulation properties of milk from Sarda ewes. J. Dairy Sci. 97:72477257. http://dx.doi.org/10.3168/jds.2014-8138.

Pazzola, M., M. L. Dettori. E. Pira, A. Noce, P. Paschino, and G. M. Vacca. 2014b. Effect of polymorphisms at the casein gene cluster on milk renneting properties of the Sarda goat. Small Rumin. Res. 117:124-130.

Pazzola, M., M. L. Dettori, G. Piras, E. Pira, F. Manca, O. Puggioni, A. Noce, and G. M. Vacca. 2013. The effect of long-term freezing on renneting properties of Sarda sheep milk. Agric. Conspec. Sci. $78: 275-279$.

Poulsen, N. A., H. P. Bertelsen, H. B. Jensen, F. Gustavsson, M. Glantz, H. Lindmark Månsson, A. Andrén, M. Paulsson, C. Bendixen, A. J. Buitenhuis, and L. B. Larsen. 2013. The occurrence of noncoagulating milk and the association of bovine milk coagulation properties with genetic variants of the caseins in 3 Scandinavian dairy breeds. J. Dairy Sci. 96:4830-4842.

Pugliese, C., A. Acciaioli, S. Rapaccini, G. Parisi, and O. Franci. 2000. Evolution of chemical composition, somatic cell count and renneting properties of the milk of Massese ewes. Small Rumin. Res. 35:71-80.

SAS Institute Inc. 2001. SAS User's Guide: Statistics. Release 8.2. SAS Institute, Inc., Cary, NC.

Sevi, A., L. Taibi, M. Albenzio, A. Muscio, and G. Annicchiarico. 2000. Effect of parity on milk yield, composition, somatic cell count, renneting parameters and bacteria counts of Comisana ewes. Small Rumin. Res. 37:99-107.

Tyrisevä, A.-M., T. Ikonen, and M. Ojala. 2003. Repeatability estimates for milk coagulation traits and non-coagulation of milk in Finnish Ayrshire cows. J. Dairy Res. 70:91-98.

Vacca, G. M., M. L. Dettori, F. Balia, S. Luridiana, M. C. Mura, V. Carcangiu, and M. Pazzola. 2013. Sequence polymorphism at the growth hormone GH1/GH2-N and GH2-Z gene copies and their relationship with dairy traits in domestic sheep (Ovis aries). Mol. Biol. Rep. 40:5285-5294.

Verdier-Metz, I., J. B. Coulon, P. Pradel, C. Viallon, and J. L. Berdague. 1998. Effect of forage conservation (hay or silage) and cow breed on the coagulation properties of milks and on the characteristics of ripened cheeses. J. Dairy Res. 65:9-21.

Wedholm, A., L. B. Larsen, H. Lindmark-Mansson, A. H. Karlsson, and A. Andren. 2006. Effect of protein composition on the cheesemaking properties of milk from individual dairy cows. J. Dairy Sci. 89:3296-3305. 